\title{
Rainbow trout Oncorhynchus mykiss ladderlectin, but not intelectin, binds viral hemorrhagic septicemia virus IVb
}

\author{
A. Reid, K. M. Young, J. S. Lumsden* \\ Fish Pathology Laboratory, Department of Pathobiology, Ontario Veterinary College, University of Guelph, \\ Guelph, Ontario N1G 2W1, Canada
}

\begin{abstract}
The innate immune system of fish is critical for rapid detection and immediate response to infection, as well as to orchestrate the adaptive branch of the immune system. Rainbow trout Oncorhynchus mykiss ladderlectin and intelectin are plasma pattern recognition receptors (PRR) for bacterial and fungal pathogens of rainbow trout, but their role as PRRs for virus is unknown. Viral hemorrhagic septicemia virus (VHSV) IVb is a recently described fish pathogen in the Great Lakes, and rainbow trout can be experimentally infected. Using an indirect enzyme-linked immunosorbent assay, rainbow trout plasma ladderlectin significantly $(\mathrm{p}<0.05)$ bound purified VHSV while intelectin did not. In addition, plasma ladderlectin but not intelectin was eluted from a VHSV-conjugated Toyopearl column using EDTA. Protein identification was confirmed with polyclonal antiserum used with slot immunoblot, 1-dimensional sodium dodecyl sulphate polyacrylamide electrophoresis, and Western immunoblot.
\end{abstract}

KEY WORDS: Oncorhychus mykiss - Pattern recognition receptor - Viral hemorrhagic septicemia virus $\cdot$ Innate immunity $\cdot$ Plasma proteins $\cdot$ Binding $\cdot$ Ladderlectin $\cdot$ Intelectin

\section{INTRODUCTION}

The innate immune system, either soluble or cellassociated, is undeniably critical in recognition of viral infection and orchestrating the initial response to infection. These components are germline-encoded, constitutively expressed, and identify potential pathogens based on stereotypic recognition of conserved molecular patterns (pattern recognition receptors, or PRRs). In humans, who have relatively well-characterised innate immune systems, cell-associated PRRs such as TOLL-like receptors (TLRs), NOD-like receptors (NLRs), and RIG-I like DNA helicases (RLRs) are of paramount importance for sensing both RNA and DNA virus infections and for initiating the adaptive immune response as well as interferon and Mx protein production (Akira et al. 2006). Soluble PRRs such as mannanbinding lectin, collectins, and natural antibody are critical for binding and suppressing major viral infections such as influenza (Kase et al. 1999, Jayasekera et al. 2007) and HIV (Saifuddin et al. 2000). In fish, the picture is less clear, although orthologous proteins for mammalian TLRs, NLRs, C-type lectins, and complement receptors have all been identified with multiple isoforms present for some TLRs, lectins, and complement components (Aoki et al. 2008). Fish RLRs have been cloned, and overexpression results in protective induction of interferon and Mx proteins (Biacchesi et al. 2009).

Viral hemorrhagic septicemia virus (VHSV) genotype IVb is a major pathogen of multiple species of fish present in the Great Lakes ecosystem since 2005 (Bowser 2009). While VHSV genotype IV is of concern in North America as an emerging pathogen, the majority of work to date in fish utilizes the European genotype I virus. VHSV activates the innate immune system of fish; DNA vaccines for VHSV have conferred high levels of Mx protein expression at the site of injection 
in rainbow trout by $7 \mathrm{~d}$ and lasting up to $21 \mathrm{~d}$ (Acosta et al. 2005). A DNA vaccine for VHSV conferred shortterm protection of rainbow trout Oncorhynchus mykiss from infection with heterologous rhabdoviruses and the unenveloped nodavirus of turbot (Sommerset et al. 2003). Resistance was hypothesized to be due to the initial inflammatory response that is likely to produce innate antiviral proteins such as interferon and $\mathrm{Mx}$ (Sommerset et al. 2003). Mx proteins are one of the major families of interferon-stimulated proteins resulting from innate immune recognition of viral infection (Ellis 2001). More recently, VHSV has been shown to stimulate multiple components of the innate immune system. In gilthead seabream Sparus aurata, VHSV has been shown to recruit and increase the activity of natural cytotoxic cells (NCC) (Esteban et al. 2008). Rainbow trout TLR9 was upregulated at the site of injection of VHSV glycoprotein G in muscle, suggesting the recruitment of dendritic cells to the site; in the head kidney and spleen there was transcriptional increase of tumor necrosis factor alpha and interleukin-6, which are cytokines known to be upregulated by TLR9 activated by unmethylated CpG DNA (Ortega-Villaizan et al. 2009). In addition, the RIGI/MAVS pathway of double stranded RNA-stimulated interferon induction has been documented in numerous fish species (Biacchesi et al. 2009), and Mx transcript upregulation has been shown in rainbow trout (Acosta et al. 2005) in response to VHSV infection. In Japanese flounder Paralichthys olivaceus, VHSV infection upregulates the hepatic expression of C3 and complement regulatory proteins (Byon et al. 2006).

Lectins are cell-associated or circulating proteins involved in recognition and binding of virions. Human and recombinant human mannose binding lectin (MBL) bind to and prevent infection with influenza A, even in absence of complement activation, and anti-viral activity was prevented by known inhibitors of MBL (Kase et al. 1999). In rodent models of influenza infection, both soluble mouse MBL and rat surfactant protein D inhibited replication of influenza A unless lectin-inhibiting saccharide solutions were used to lavage the trachea and bronchi (Reading et al. 1997). MBL has also been shown to bind human immunodeficiency virus as both surface-associated and soluble lectin, selectively identifying viral proteins displayed on the virion's surface and binding was again blocked with known MBL inhibitors (Saifuddin et al. 2000). Indeed, a syndrome of increased susceptibility to viral and fungal infections is known in MBL-deficient humans (Kase et al. 1999). In contrast to mammals, little evidence exists for lectin-virus interaction in fish. Recently VHSV has been shown to stimulate rainbow trout hepatic mRNA expression of the lectin serum amyloid A, a major acute phase reactant, via TLR signalling (Rebl et al. 2009).
Ladderlectin and intelectin are 2 previously identified lectins in rainbow trout (Young et al. 2007, Russell et al. 2008a,b) implicated as PRRs since they bind bacterial, protozoal, and fungal pathogens. Immunohistochemical staining of healthy rainbow trout has demonstrated that both ladderlectin and intelectin are found in leukocytes and mucosal epithelia (Russell et al. 2009). In diseased fish, ladderlectin and intelectin are present in the intercellular spaces surrounding colonies of Aeromonas salmonicida, fungal hyphae, and the protozoans Ichthyophthirius multifilis and Loma salmonae (Russell et al. 2009). Based on this evidence for ladderlectin and intelectin having a strong role in immunosurveillance and broad pathogen recognition, we hypothesised that rainbow trout ladderlectin and intelectin would interact with VHSV IVb.

\section{MATERIALS AND METHODS}

Plasma binding assays. Rainbow trout plasma was derived in 2005 from subadult and adult rainbow trout (Lyndon Hatcheries, New Dundee, Ontario, Canada) that were held in the Central Animal Facility at the University of Guelph (Guelph, Ontario, Canada) in single-pass well water, graded by size, and maintained on standard commercial trout feed (Martin Mills). Whole blood was collected from terminal caudal venipucture into tubes treated with $18 \mathrm{mM}$ calcium chloride buffer (9:1 whole blood:buffer) on ice. Whole blood was centrifuged that day $\left(5000 \times g, 4^{\circ} \mathrm{C}, 20 \mathrm{~min}\right)$, and the plasma was decanted, pooled, and frozen at $-20^{\circ} \mathrm{C}$ until required. Aliquoted pooled plasma samples represent over a dozen fish. For use in assays, plasma was thawed with approximately $30 \mathrm{IU}$ heparin per $40 \mathrm{ml}$ of plasma. Heparinised plasma was dialysed in Spectrapore membrane tubing (Spectrum Medical) and incubated overnight in 10 volumes of $\mathrm{TBSCa}^{2+}(50 \mathrm{mM}$ Tris base, $50 \mathrm{mM} \mathrm{NaCl}, 5 \mathrm{mM} \mathrm{CaCl}_{2}, \mathrm{pH} \mathrm{7.6)}$ at $4^{\circ} \mathrm{C}$. It was then decanted and centrifuged $\left(5000 \times g, 4^{\circ} \mathrm{C}\right.$, $20 \mathrm{~min}$ ) to remove any fibrinogen before syringe filtration (0.2 $\mu \mathrm{m}$; Nalgene Company) and use in assays.

VHSV IVb was isolated from freshwater drum Aplodinotus grunniens in Lake Ontario in 2005 (CEFAS strain U13653; Lumsden et al. 2007). Virus was cultured as described by Al-Hussinee et al. (2010) using EPC cells (ATCC CRL-2872) and minimum essential medium with $2 \mathrm{mM}$ L-glutamine, 100 units penicillin, 100 units streptomycin, $2.5 \mu \mathrm{g}$ of amphoteracin B and $10 \%$ [v/v] certified inactivated fetal bovine serum (Invitrogen) with the initial $\mathrm{pH}$ adjusted to approximately 5.6 to promote fusion (Estepa \& Coll 1997), based on phenyl red indicator in the media, using $7 \%$ NaHCO3. Viral propagation was then performed as per Al-Hussinee et al. (2010) at a pH of 7.6. The cells were incu- 
bated at $15^{\circ} \mathrm{C}$ until complete CPE was noted in approximately $5 \mathrm{~d}$. The supernatant was centrifuged $(5000 \times g$, $\left.4^{\circ} \mathrm{C}, 20 \mathrm{~min}\right)$ to remove the cell pellet and then ultracentrifuged $\left(130000 \times g, 4^{\circ} \mathrm{C}, 3 \mathrm{~h}\right)$ using a $5 \mathrm{ml} 25 \% \mathrm{v} / \mathrm{v}$ glycerol cushion in TNE $(0.01 \mathrm{M} \mathrm{NaCl}, 0.05 \mathrm{M}$ Tris$\mathrm{HCl}, 0.001 \mathrm{M}$ EDTA, pH 7.5). The liquid was decanted and the viral pellet was resuspended in $200 \mu \mathrm{m}$ TNE buffer and frozen at $-80^{\circ} \mathrm{C}$ until needed.

Indirect enzyme linked immune-sorbent assay (ELISA) for lectin binding to VHSV. Plasma binding to VHSV was tested by coating the wells of 2 Nunc Polysorp 96 well plates (ThermoScientific) with $200 \mu \mathrm{l}$ of a 1:500 dilution of glycerol-purified VHSV in coating buffer (1.59 $\mathrm{g} \mathrm{NaCO}_{3}, 2.94 \mathrm{~g} \mathrm{NaHCO}_{3} \mathrm{l}^{-1}$, pH 9.5). This was allowed to incubate overnight at $4^{\circ} \mathrm{C}$. The next morning, wells were washed with 3 changes of $300 \mu \mathrm{l}$ phosphate-buffered saline, $\mathrm{pH} 7.42$, with $0.5 \%$ Tween 20 (PBS-T). Four replicate wells of 2 samples of dialysed rainbow trout plasma in PBS-T were mixed 1:10 with a solution of $1 \%$ skim milk powder in PBS-T; $200 \mu \mathrm{l}$ of the plasma mixture was applied to each well and incubated at room temperature for $1 \mathrm{~h}$. A similar volume of PBS-T was added to negative control wells. The plate was then washed as above and $5 \%$ skim milk powder w/v was mixed into PBS-T and $200 \mu \mathrm{l}$ was used to block each well and incubated for $1 \mathrm{~h}$. Wells were washed as above, and $150 \mu$ of a 1:8000 dilution of polyclonal rabbit anti-rainbow trout ladderlectin antibody in $1 \%$ skim milk (w/v in PBS-T) were applied to the rainbow plasma (Young et al. 2007). After $1 \mathrm{~h}$, wells were washed and 100 $\mu$ l of a 1:20000 dilution of horseradish peroxidase-conjugated goat anti-rabbit immunoglobulin (Dako Denmark) in PBS-T with $1 \%$ skim milk powder was applied as above. The plate was incubated for $1 \mathrm{~h}$ and then washed 3 times as above before peroxidase activity was detected with 1-Step Ultra TMB-ELISA (Pierce). After $30 \mathrm{~min}$ the reaction was stopped with $100 \mathrm{ml}$ of $1 \mathrm{M} \mathrm{H}_{2} \mathrm{SO}_{4}$. All incubations occurred at room temperature with gentle agitation. Optical densities were read at $450 \mathrm{~nm}$ on the Ceres 900 EIA workstation (Bio-Tek Instruments). Absorbance was corrected from blank wells. Means, confidence intervals, and degrees of freedom were calculated and a Student's $t$-test was performed for significance $(\mathrm{p}<$ $0.05)$.

VHSV-conjugated Toyopearl column assay. Approximately $40 \mathrm{mg}$ of glycerol cushion-purified VHSV was coupled to $4 \mathrm{ml}$ of Toyopearl AF Amino 650M resin (Tosoh Biosciences). The gel resin was washed according to manufacturer's directions and then mixed with 30 mg N-ethyl-N'-(3-dimethyl amino propyl) carbodiiamide hydrochloride and $10 \mathrm{mg}$ VHSV per $\mathrm{ml}$ of gel in TNE buffer all in $1 \mathrm{M} \mathrm{NaCl}$ (pH 5.5) and incubated with gentle agitation at room temperature for $48 \mathrm{~h}$. After incubation, the gel suspension was washed gently with $1 \mathrm{M} \mathrm{NaCl}$ to remove unreacted ligand. As a control, a separate suspension of gel resin was treated as above but without the addition of VHSV. Both preparations were blocked according to manufacturer's directions with $0.2 \mathrm{M}$ sodium acetate and $0.2 \mathrm{M}$ acetic anhydride, washed with $\mathrm{TBSCa}^{2+}$ and packed according to manufacturer's directions into a $16 \mathrm{ml}$ column with $\mathrm{TBSCa}^{2+}$ and a pump (Peristaltic Pump P1, GE Healthcare) for $24 \mathrm{~h}$. Dialysed plasma diluted in 2 volumes of $\mathrm{TBSCa}^{2+}$ was passed twice through the column, washed in $200 \mathrm{ml}$ of $\mathrm{TBSCa}^{2+}$, and $40 \mathrm{ml}$ of a $300 \mathrm{mM}$ EDTA solution was used to competitively elute protein bound to VHSV. Eluate was collected in $5 \mathrm{ml}$ fractions and later pooled for SDS-PAGE and Western immunoblots.

One-dimensional sodium dodecylsulphate polyacrylamide gel electrophoresis (1-D SDS-PAGE). Whole rainbow trout plasma and VHSV-Toyopearl binding assays were characterised using 12.5 to $15 \%$ SDS-PAGE (Laemmli 1970) under reducing conditions with the Bio-Rad Mini-PROTEAN electrophoresis system (Bio-Rad). Samples were diluted in $30 \times$ sample buffer (0.2 M Tris-HCl pH 6.8, 8 \% SDS, $40 \%$ glycerol, $0.004 \%$ bromophenol blue, Bio-Rad) with the addition of $50 \mathrm{mM}$ dithiothreitol before heating at $100^{\circ} \mathrm{C}$ for $5 \mathrm{~min}$ and centrifugation at $3000 \times g$ for $3 \mathrm{~min}$. Gels were stained overnight in SYPRO Ruby (Molecular Probes), destained as per the manufacturer's instructions and imaged on the Gene Genius Bioimaging system (Syngene). Molecular masses were determined by comparison with a broad range molecular weight marker (New England Biolabs).

Slot immunoblot. Slot immunoblots were performed on pooled fractions collected from the VHS Toyopearl column. Rainbow trout plasma and $\mathrm{TBSCa}^{2+}$ were used as positive and negative controls. Protran BA 83 nitrocellulose membrane $(0.2 \mu \mathrm{m}$; Whatman) was cut to length, wetted with $\mathrm{TBSCa}^{2+}$ and placed in a MiniFold II slot blot apparatus ( $24 \mathrm{~cm}$; Scleicher \& Schuell). Vacuum was used to transfer $200 \mu$ l aliquots of pooled eluate and controls into the membrane. PBS-T was used as a buffer, and all incubation was conducted at room temperature with gentle agitation. A 1:5000 dilution of polyclonal rabbit anti-trout ladderlectin serum in PBS-T was used for the primary antibody, and a HRP conjugated goat anti-rabbit immunoglobulin (Dako Denmark) diluted 1:20000 in PBS-T was used as a secondary antibody (Young et al. 2007). Blots were developed with ECL-Plus Western Blotting Detection kit (GE Healthcare Biosciences) and were visualized on the Typhoon 9410 Imaging System (GE Healthcare Biosciences). Rainbow trout intelectin was identified in an identical fashion except for the use of polyclonal rabbit anti-rainbow trout intelectin antibody (Russell et al. 2008b, 2009) as the primary antibody. 


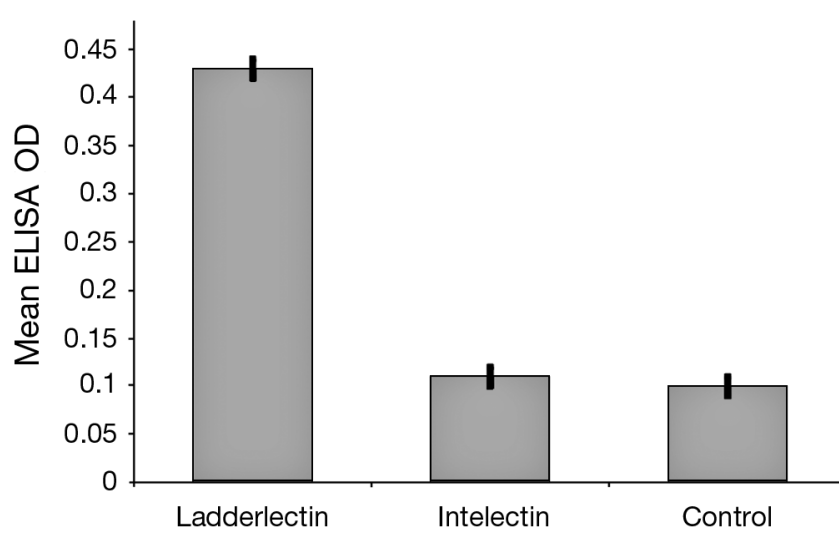

Fig. 1. Mean ELISA optical density (OD) and 95\% confidence intervals of rainbow trout ladderlectin or intelectin bound to VHSV and detected using polyclonal antisera to either protein, compared to control wells without VHSV. Rainbow trout ladderlectin binds VHSV significantly $(p<0.05)$ more than rainbow trout intelectin, which was not different from VHSVfree control wells

Western immunoblots. Proteins separated by SDSPAGE were electroblotted onto polyvinylidene difluoride transfer membranes (Millipore Immobilon-PSQ; pore size $0.45 \mu \mathrm{m}$; Millipore Corporation) in transfer buffer (192 mM glycine, $25 \mathrm{mM}$ Tris, $25 \%$ [v/v] methanol, $\mathrm{pH}$ 8.3) on the Mini Trans-Blot Electrophoretic Transfer Cell (Bio-Rad) as per Russell et al. (2008a). Whole rainbow trout plasma was used as a control for column fractions. Prestained broad range protein marker (New England Biolabs) was used as a molecular weight standards. Blots were developed as described for slot immunoblots.

\section{RESULTS}

To determine if VHSV could be bound by rainbow trout plasma lectins, we probed the plasma proteins bound to VHSV-coated wells with polyclonal rabbit antibody to ladderlectin and intelectin. The VHSV indirect ELISA for plasma binding resulted in a mean
OD of $0.43 \pm 0.1$ for rainbow trout ladderlectin (Fig. 1A), $0.12 \pm 0.1$ for intelectin (Fig. 1B) and $0.098 \pm$ 0.1 (Fig. 1C) for control wells without coated VHSV with 2 samples of pooled rainbow trout plasma representing over a dozen individual fish. Binding was significantly higher for ladderlectin than intelectin or control VHSV-free wells $(\mathrm{p}<0.05)$ while the intelectin binding was not significantly different to the control wells $(p>0.05)$ indicating that intelectin does not significantly bind to VHSV, at least under the conditions used. Results were consistent with a replicate plate from the same plasma pool (data not shown).

The EDTA-eluted plasma proteins bound to the VHSV-Toyopearl column from 3 different $5 \mathrm{ml}$ aliquots of eluate were applied to the slot blot apparatus and probed with rabbit polyclonal antibody to rainbow trout intelectin and ladderlectin (Fig. 2) as well as whole plasma controls. Intelectin was not detected in the column eluate on slot immunoblot but had a strong positive signal in unbound whole rainbow trout plasma, indicating intelectin did not bind the VHSVToyopearl column (Fig. 2), as expected from the indirect ELISA results (Fig. 1). Slot immunoblots probed with anti-rainbow trout ladderlectin peptide were strongly positive in unbound whole plasma control as well as positive on the 3 samples of EDTA eluate from the VHSV-Toyopearl column (Fig. 2), in agreement with earlier ELISA results (Fig. 1). Eluate from a control Toyopearl column lacking conjugated VHSV had no positives on slot immunoblot for either rainbow trout ladderlectin or intelectin (data not shown). When the EDTA eluate of rainbow trout proteins bound to the VHSV-Toyopearl column was analysed using 1-D SDS-PAGE, numerous distinct bands were identified at $67,58,56,50,38,28,20$, and $16 \mathrm{kDa}$ (Fig. 3); the faint $16 \mathrm{kDa}$ band is consistent with the position of rainbow trout ladderlectin monomer (Russell et al. 2008a). Eluate from the control column without bound VHSV analyzed using SDS-PAGE had no protein bands present (data not shown). The blotted gel was probed with polyclonal rabbit antibody to rainbow trout ladderlectin and 2 distinct bands were detected at 16 and $28 \mathrm{kDa}$ (Fig. 3), consistent with rainbow trout ladder-

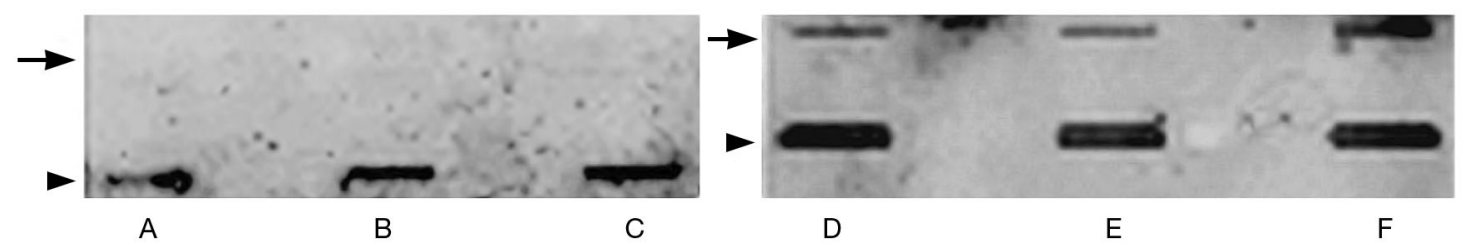

Fig. 2. Rainbow trout Oncorhynchus mykiss ladderlectin (D-F) but not intelectin (A-C) was detected in slot immunoblot of successive fractions eluted from a VHSV-Toyopearl (arrow, upper row) using polyclonal antisera to ladderlectin and intelectin, respectively. Whole rainbow trout plasma (small arrowhead, lower row) is detected using polyclonal antisera to ladderlectin and intelectin, respectively, for comparison 

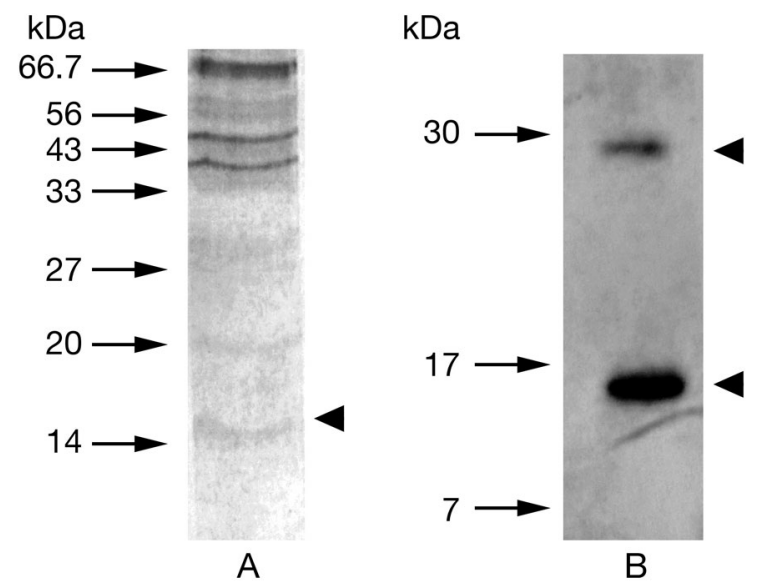

Fig. 3. (A) $12.5 \%$ 1-D reduced polyacrylamide gel electrophoresis and (B) Western blot of rainbow trout Oncorhynchus mykiss plasma proteins eluted from a VHSV-Toyopearl column using EDTA. (A) Arrowhead indicates a faint $16 \mathrm{kDa}$ band consistent with rainbow trout ladderlectin monomer and (B) arrowheads indicate bands at 16 and $28 \mathrm{kDa}$ consistent with rainbow trout ladderlectin

lectin (Russell et al. 2008a). The specificity of the polyclonal antibodies to rainbow trout intelectin and ladderlectin used in the present study has been previously described (Russell et al. 2008a,b, Young et al. 2007). Western blot analysis of whole rainbow trout plasma and partially purified lectin preparations from plasma yield $16 \mathrm{kDa}$ and $37 \mathrm{kDa}$ bands for ladderlectin and intelectin (not shown), respectively, in agreement with the results obtained in the present study (Fig. 3). The $16 \mathrm{kDa}$ ladderlectin monomer has been sequenced on numerous occasions from both 1- and 2-D SDS-PAGE (Russell et al. 2008a,b, Young et al. 2007).

\section{DISCUSSION}

Our detection of ladderlectin binding to VHSV is consistent with ladderlectin's previously demonstrated association with a broad range of pathogens (Young et al. 2007, Russell et al. 2008a,b, 2009). Rainbow trout ladderlectin binds Aeromonas salmonicida, A. hydrophila, Yersinia ruckeri, and Pseudomonas sp. as well as chitin, a component of the exterior of fungal, microsporidian, and metazoan pathogens (Russell et al. 2008a). Using immunohistochemistry, ladderlectin is present within lesions of diseased fish and is in intimate contact with A. salmonicida, Flavobacterium psychrophilum, fungal hyphae, and surrounding Ichthyophthirius multifiliis and Loma salmonae (Russell et al. 2009).

While ladderlectin is typically detected as a $16 \mathrm{kDa}$ monomer with SDS-PAGE under reducing conditions (Hoover et al. 1998, Russell et al. 2008a), it is not un- common to find higher molecular weight bands of ladderlectin on Western blot, possibly representing different oligomers of ladderlectin present in plasma (Russell et al. 2008a). Both rainbow trout ladderlectin and intelectin require calcium for binding activity, which is why both are consistently eluted using the calciumchelating agent EDTA (Russell et al. 2008a,b).

The ladderlectin bands detected by 1-D SDS-PAGE were faint, which is consistent with the low plasma concentrations of ladderlectin in some populations of rainbow trout (Young et al. 2007). As stated above, the specificity of the polyclonal antibodies for ladderlectin and intelectin, used in the present study, has been confirmed previously using Western blots and sequencing (Young et al. 2007, Russell et al. 2008a,b). While the antibody used in this assay detects both known isoforms of ladderlectin, not all detectable plasma ladderlectin binds previously demonstrated ladderlectin targets (Russell et al. 2008a). On Western blots of rainbow trout plasma from 2-D SDS-PAGE, 5 ladderlectin monomers were identified, but on binding assays for Aeromonas salmonicida only 2 of the 5 spots of ladderlectin monomer were present, suggesting different monomers of ladderlectin have different binding affinities (Russell et al. 2008a). Additionally, ladderlectin is found on the surface of and within the cytoplasm of leukocytes, as well as branchial and intestinal epithelial cells (Russell et al. 2008a, 2009), and there may be cell- and tissue-dependent expression of isoforms, consistent with known lectins such as murine mannose binding lectin (Wagner et al. 2003) and human ficolin (Ohashi \& Erickson 1998). The implications for the present experiments are not presently known. Additionally, the identity of the numerous other molecular weight bands identified on SDS-PAGE are not known; however, this is a consistent finding in previous plasma binding assays using bacteria or chitin as targets (Young et al. 2007, Russell et al. 2008a,b) and demonstrates that rainbow trout have multiple PRRs that may be involved in innate defense to VHSV.

That ladderlectin binds to VHSV directly suggests it may have several potential roles in defense. Direct binding of lectins to viruses can prevent infection; MBL and bovine conglutinin, independent of complement activation, inhibit the haemagglutinating ability of influenza viruses and reduce plaque formation as well as infection of neighbouring cells by interfering with attachment to cell surface targets (Kase et al. 1999). The effect can be neutralized by the addition of MBL inhibitors: EDTA, mannose, or antibody to human MBL (Kase et al. 1999). Lectins can also stimulate the lectin pathway of complement and directly opsonize pathogens for phagocytosis (Ewart et al. 2001) and upregulate transcription of complement and complement regulatory proteins (Byon et al. 2006), and enhance NCC 
recruitment and activation in seabream (Esteban et al. 2008). These mechanisms may also be involved in immediate defense against VHSV infection. Salmon serum lectin (SSL), very closely related to rainbow trout ladderlectin, not only directly binds to Vibrio anguillarum and Aeromonas salmonicidia, but SSL increases phagocytosis and killing by macrophages when co-incubated with those bacteria (Ewart et al. 1999, Ottinger et al. 1999). As VHSV enters rainbow trout by binding to gill epithelial cells and spreads in part by macrophage phagocytosis (Brudeseth et al. 2008), ladderlectin's presence in gill epithelial cells and leucocytes, as well as in plasma (Russell et al. 2008a), ideally situate it for interaction with VHSV. Rainbow trout ladderlectin is known to have binding specificities for glucose, N-acetyl-glucosamine, mannose, fucose, and maltose (Jensen et al. 1997), which suggests that one or more of these sugars are present in carbohydrates on the glycoprotein outer layer of VHSV. VHSV can also be purified using the plant lectin concanavalin-A, which primarily recognizes mannose groups (Perez et al. 1998) but also binds agarose (Bernhard \& Avrameas 1971), a monosaccharide derivative of glucose. Rainbow trout intelectin, by contrast, is known to bind mannose and N-acetyl-glucosamine (Russell et al. 2008b). Previous work with numerous animal and plant lectins has shown that galactose- and galactosamine-specific lectins cannot aggregate several isolates of VHSV genotype 1 while another VHSV isolate was poorly bound by concavalin-A (Bernard et al. 1985) suggesting that surface carbohydrate is highly strain specific and may influence the ability of the innate immune system to recognise different isolates. Additionally, neutralisation antibody sensitivity to viruses such as HIV-1 is influenced by the cell type used for culture (Sawyer et al. 1994), so it is conceivable that VHSV could have different lectin binding sensitivities if passaged through a rainbow trout origin cell line rather than on a heterologous cell line. The glycoprotein of VHSV is known to have the peripheral carbohydrates glucose, mannose, N-acetylglucosamine, galactose, sialic acid, and fucose (Coll 1995), and these should offer opportunity for recognition by the carbohydrate recognition domain of either intelectin or ladderlectin. As lectin binding is influenced by spatial arrangement of carbohydrate groups, it is possible that the carbohydrate groups are not present in the proper conformation for intelectin binding, that ladderlectin has higher affinity for VHSV, or that the peripheral sugars required for intelectin binding are not present on the glycoprotein layer in sufficient quantity for detectable binding activity of intelectin.

Identification of the physiological significance of ladderlectin-VHSV binding remains to be elucidated. Ladderlectin is often present in normal trout plasma at a very low concentration, and therefore purification of significant quantities of the lectin for downstream function is very difficult. Uribe (2010) attempted 3 different protein expression systems to produce recombinant SSL, a C-type lectin with very high homology to rainbow trout ladderlectin, and did not find a system that yielded functional SSL in quantity. The same study demonstrated that SSL lacks the necessary collagenous domain to interact with complement components (Uribe 2010), as does rainbow trout ladderlectin (Russell et al. 2008a). Nonetheless, ladderlectin binding VHSV is a novel role for a fish PRR and offers a mechanism for some of the innate immune responses to VHSV infection demonstrated by other researchers.

Acknowledgements. Funding was provided by NSERC Strategic and Discovery grants and by the Great Lakes Fisheries Commission. A.R. is a recipient of an Ontario Veterinary College Fellowship. Thanks to S. Russell for reading the manuscript.

\section{LITERATURE CITED}

Acosta F, Petrie A, Lockhart K, Lorenzen N, Ellis AE (2005) Kinetics of Mx expression in rainbow trout (Oncorhynchus mykiss W) and Atlantic salmon (Salmo salar L) parr in response to VHSV-DNA vaccination. Fish Shellfish Immunol 18:81-89

Akira S, Uematsu S, Takeuchi O (2006) Pathogen recognition and innate immunity. Cell 124:783-801

Al-Hussinee L, Huber P, Russell S, LePage V and others (2010) Viral hemorrhagic septicemia virus IVb experimental infection of rainbow trout, Oncorhynchus mykiss (Walbaum), and fathead minnow, Pimphales promelas (Rafinesque). J Fish Dis 33:347-360

Aoki T, Tomokazu T, Santos MD, Hidehiro K, Hirono I (2008) Molecular innate immunity in teleost fish: review and future perspectives. In: Tsukamoto $K$, Kawamura $T$, Takeuchi T, Beard TD Jr, Kaiser MJ (eds) Fisheries for global welfare and environment. 5th World Fisheries Congress, p 263-276

Bernard J, Bearzotti-Le Berre M, de Kinkelin P (1985) Viral hemorrhagic septicaemia in rainbow trout: attempt to relate interferon production, antibody synthesis and structure of the virus with the mechanism of virulence. Ann Inst Pasteur Virol 136:13-26

$>$ Bernhard W, Avramas S (1971) Ultrastructural visualization of cellular carbohydrate components by means of concavalin-A. Exp Cell Res 64:232-236

> Biacchesi S, LeBerre M, Lamoureux A, Louise Y, Lauret E, Boudinot P, Brémont M (2009) MAVS plays a major role in induction of the fish innate immune response against RNA and DNA viruses. J Virol 83:7815-7827

Bowser P (2009) Fish diseases: viral hemorrhagic septicemia (VHS). Northeastern Regional Aquaculture Center Publication no. 201

Brudeseth BE, Skall HF, Evensen $\varnothing ~(2008)$ Difference in virulence of marine and freshwater isolates of viral hemorrhagic septicemia virus in vivo correlate with in vitro ability to infect gill epithelial cells and macrophages of rainbow trout (Oncorhynchus mykiss). J Virol 82: 10359-10365 
Byon JY, Ohira T, Hirono I, Aoki T (2006) Comparative immune responses in Japanese flounder, Paralichthys olivaceus, after vaccination with viral hemorrhagic septicemia virus (VHSV) recombinant glycoprotein and DNA vaccine using a microarray analysis. Vaccine 24:921-930

Coll JM (1995) The glycoprotein G of rhabdoviruses. Arch Virol 140:827-851

Ellis AE (2001) Innate host defense mechanisms of fish against viruses and bacteria. Dev Comp Immunol 25: 827-829

Esteban MA, Meseguer K, Tafalla C, Cuesta A (2008) NK-like and oxidative burst activities are the main early cellular innate immune responses activated after virus inoculation in reservoir fish. Fish Shellfish Immunol 25:433-438

Estepa A, Coll A (1997) Temperature and pH requirements for viral haemorrhagic septicemia virus induced cell fusion. Dis Aquat Org 28:185-189

Ewart KV, Johnson SC, Ross NW (1999) Identification of a pathogen-binding lectin in salmon serum. Comp Biochem Physiol C 123:9-15

Ewart KV, Johnson SC, Ross NW (2001) Lectins of the innate immune system and their relevance to fish health. ICES J Mar Sci 58:380-385

Hoover GJ, El-Mowafi A, Simko E, Kocal TE, Ferguson HW, Hayes MA (1998) Plasma proteins of rainbow trout (Oncorhynchus mykiss) isolated by binding to lipopolysaccharide from Aeromonas salmonicida. Comp Biochem Physiol B 120B:559-569

Jayasekera JP, Moseman EA, Carrol MC (2007) Natural antibody and complement mediate neutralization of influenza virus in the absence of prior immunity. J Virol 81:3487-3494

> Jensen LE, Thiel S, Petersen TE, Jensenius JC (1997) A rainbow trout lectin with multimeric structure. Comp Biochem Physiol B 116:385-390

Kase T, Suzuki Y, Kawau T, Sakamoto T and others (1999) Human mannan-binding lectin inhibits the infection of influenza A virus without complement. Immunology 97: 385-392

Laemmli UK (1970) Cleavage of structural proteins during assembly of the head of bacteriophage T4. Nature 227: 680-685

Lumsden JS, Morrison B, Yason C, Russell S and others (2007) Mortality event in freshwater drum Aplodinotus grunniens from Lake Ontario, Canada, associated with viral hemorrhagic septicemia virus Type IV. Dis Aquat Org 76: 99-111

Ohashi T, Erickson HP (1998) Oligomeric structure and tissue distribution of ficolins from mouse, pig and human. Arch Biochem Biophys 360:223-232

Ortega-Villaizan M, Chico V, Falco A, Perez L, Coll JM, Estapa A (2009) The rainbow trout TLR9 gene and its role in the immune responses elicited by a plasmid encoding the glycoprotein $\mathrm{G}$ of the viral haemorrhagic septicaemia rhabdovirus (VHSV). Mol Immunol 46:1710-1717

Editorial responsibility: V. Gregory Chinchar, Jackson, Mississippi, USA
Ottinger CA, Johnson SC, Ewart KV, Brown LL, Ross NW (1999) Enhancement of anti-Aeromonas salmonicida activity in Atlantic salmon (Salmo salar) macrophages by a mannose-binding lectin. Comp Biochem Physiol C 123: 53-59

Perez L, Estapa A, Coll JM (1998) Purification of the glycoprotein $\mathrm{G}$ from viral hemorrhagic septicaemia virus, a fish rhabdovirus, by lectin affinity chromatography. J Virol Methods 76:1-8

Reading PC, Morey LS, Crouch EC, Anders EM (1997) Collectin-mediated antiviral host defense of the lung: evidence from influenza virus infection of mice. J Virol 71:8204-8212

> Rebl A, Goldammer T, Fischer U, Köllner B, Sayfert HM (2009) Characterization of two key molecules of teleost innate immunity from rainbow trout (Oncorhynchus mykiss): MyD88 and SAA. Vet Immunol Immunopathol 131:122-126

Russell S, Young KM, Smith M, Hayes MA, Lumsden JS (2008a) Cloning, binding properties, and tissue localization of rainbow trout (Oncorhynchus mykiss) ladderlectin. Fish Shellfish Immunol 24:669-683

Russell S, Young KM, Smith M, Hayes MA, Lumsden JS (2008b) Identification, cloning and tissue localization of a rainbow trout (Oncorhynchus mykiss) intelectin-like protein that binds bacteria and chitin. Fish Shellfish Immunol 25:91-105

Russell S, Hayes MA, Lumsden JS (2009) Immunohistochemical localization of rainbow trout ladderlectin and intelectin in healthy and infected rainbow trout (Oncorhynchus mykiss). Fish Shellfish Immunol 26:154-163

Saifuddin M, Hart ML, Gewurz H, Zhang Y, Spear GT (2000) Interaction of mannose-binding lectin with primary isolates of human immunodeficiency virus type 1. J Gen Virol 81:949-955

Sawyer LS, Wrin MT, Craford-Miksza L, Potts B and others (1994) Neutralization sensitivity of human immunodeficiency virus type 1 is determined in part by the cell in which the virus is propagated. J Virol 68:1342-1349

Sommerset I, Lorenzen E, Lorenzen N, Bleie H, Nerland AH (2003) A DNA vaccine directed against a rainbow trout rhabdovirus induces early protection against a nodavirus challenge in turbot. Vaccine 21:4661-4667

Uribe E (2010) Binding specifity and recognition roles of the Atlantic salmon serum C-type lectin. PhD thesis, Dalhousie University, Halifax

Wagner S, Lynch NJ, Walter W, Schwable WJ, Loos M (2003) Differential expression of the murine mannose-binding lectins $\mathrm{A}$ and $\mathrm{C}$ in lymphoid and nonlymphoid organs and tissues. J Immunol 170:1462-1465

Young KM, Russell S, Smith M, Huber P and others (2007) Bacterial-binding activity and plasma concentration of ladderlectin in rainbow trout (Onchorhynchus mykiss). Fish Shellfish Immunol 23:305-315

Submitted: October 4, 2010; Accepted: March 14, 2011 Proofs received from author(s): May 30, 2011 